\title{
THE SMALL INDIGENOUS SPECIES (SIS) OF FISH OF NETRAKONA DISTRICT
}

\author{
BIMAL KANTA SAHA ${ }^{1}$ AND APARNA SAHA \\ Department of Zoology, Netrakona Govt. College, Netrakona-2400, Bangladesh
}

\begin{abstract}
The investigation on small indigenous species of fish (SIS) of Netrakona district was conducted from July 2003 to June 2004. A total number of 78 SIS belonging to 54 genera, 4 sub-families, 25 families and 10 orders was identified from the district. The most dominant family was Cyprinidae having 26 species under the order Cypriniformes. Puntius was the largest genus containing 7 species. The most abundant SIS was Mola (Amblypharyngodon mola) during the investigation period, whereas the least abundant SIS was Bacha (Eutropiichthys vacha). Seasonal variations were observed in the abundance of different SIS.
\end{abstract}

Key words: SIS, Puntius, Cyprinidae, Seasonal abundance, Netrakona district

\section{Introduction}

The small indigenous fish species (SIS) of Bangladesh are generally considered to be those fishes which grow to a length of less than $25 \mathrm{~cm}$ or 9 inches (Felts et al. 1996). Among the fishery commodities, the small fishes occupy an important position in the popular human food items. The SIS fishes are available in smaller water bodies like drains, ditches, ponds, lakes, beels.

Although the freshwaters of Bangladesh abound with a large variety of SIS fishes, systematic position of these fishes has not been adequately studied in the past, especially from the point of view of modern systematics. It is an accepted fact that before any management and development program relating to fish and fisheries undertaken, it is essential to determine the taxonomic status of the fish concerned. The need for the production of a comprehensive guide for identification of SIS fish fauna of the country was, therefore, greatly felt.

Although many scientists (Ahmad 1953, Bhuiyan 1964, Doha 1973, Huda et al. 2009, Islam and Ahmed 2010) reported freshwater bony fishes of different waterbodies of the country, no published report or survey regarding SIS fishes of Netrakona district is uptil now available. The water of Netrakona district is rich with a variety of fishes of commercial importance and taxonomic interest. Thus the present investigation was conducted to explore richness and diversity of SIS from different waterbodies of Netrakona district.

\footnotetext{
'Corresponding author: E-mail: bimalkantasaha@yahoo.com
} 


\section{Material and Methods}

Samples of fish specimen were collected from different waterbodies such as ponds, ditches, canals, beels, rivers of Netrakona district extending over a period of one year from July 2003 to June 2004 from commercial fishermen and from fish markets. The main rivers are the Kangsa, Someswari, Dhanu and Mogra. The beels are Bhawal, Rajdhala Manza, Garadhar, Baila etc. The haors are Dingaputa, Ganesher. Three fish landing centres (Jaria ghat of Purbodhala, Mohanganj ghat of Mohonganj and Khaliajuri ghat of Khaliajuri), two fish markets (Machh bazar and Rail Crossing bazar of Netrakona sadar) and some catch points at Barhatta, Durgapur, Kalmakanda and Madan were selected to collect fish samples and data.

Sampling was made following Backiel and Welcomme (1980). Detailed sampling information is described in Table 1. Description of the fishes was based on both direct observations on the fishes of different waterbodies and interview with the local fishermen. The specimens were primarily classified on the spot and which were difficult to identify on the spot, were preserved in 5-10 per cent formalin in plastic jars. The preserved specimens were labelled with date of collection, number and locality and brought to the department of Zoology, Netrokona Govt. College, Netrokona, Bangladesh. Identification of fishes were done following Day (1878), Munro (1955), Srivastava (1968), Jayaram (1981), Shafi and Quddus (1982), Rahman (1989).

Table 1. Description of the sampling stations used in the SIS study of Netrakona district.

\begin{tabular}{|c|c|c|c|}
\hline $\begin{array}{l}\text { Sampling } \\
\text { station }\end{array}$ & $\begin{array}{l}\text { Sampling } \\
\text { period }\end{array}$ & Description & Sampling frequency \\
\hline $\begin{array}{l}\text { St-1: } \\
\text { Durgapur, } \\
\text { Kalmakanda }\end{array}$ & $\begin{array}{l}\text { Sum (Feb- } \\
\text { Apr) }\end{array}$ & $\begin{array}{l}\text { Hot weather, minimum } \\
\text { water volume, fishes } \\
\text { become vulnerable to } \\
\text { fishing effort }\end{array}$ & $\begin{array}{l}\text { St }-1=1 \\
\text { St }-2=2 \\
\text { St }-3=1 \\
\text { St-4=1 }\end{array}$ \\
\hline $\begin{array}{l}\text { St-2: } \\
\text { Purbadhala, } \\
\text { Netrakona }\end{array}$ & Rai (May-Jul) & $\begin{array}{l}\text { Water volume increases, } \\
\text { torrential flow, difficult to } \\
\text { catch fishes }\end{array}$ & $\begin{array}{l}\text { St }-1=1 \\
\text { St }-2=2 \\
\text { St }-3=1 \\
\text { St- }-4=0\end{array}$ \\
\hline $\begin{array}{l}\text { St-3: } \\
\text { Barhatta, } \\
\text { Mohanganj }\end{array}$ & Aut (Aug-Oct) & $\begin{array}{l}\text { Water volume and current } \\
\text { moderate, fishes become } \\
\text { vulnerable to fishing gear in } \\
\text { the second half of the period }\end{array}$ & $\begin{array}{l}\text { St }-1=1 \\
\text { St }-2=2 \\
\text { St-3 }=2 \\
\text { St } 4=2\end{array}$ \\
\hline $\begin{array}{l}\text { St-4: } \\
\text { Madan, } \\
\text { Khaliajuri }\end{array}$ & Win (Nov-Jan) & $\begin{array}{l}\text { Cold weather, diminishing } \\
\text { water volume, fishes } \\
\text { become susceptible to } \\
\text { fishing gear }\end{array}$ & $\begin{array}{l}\text { St }-1=2 \\
\text { St }-2=3 \\
\text { St }-3=2 \\
\text { St- }-4=1\end{array}$ \\
\hline
\end{tabular}

Sum: Summer, Rai: Rainy season, Aut: Autumn, Win: Winter; Feb-February, AugAugust, Oct-October, Nov-November, Jan-January; St-Station. 


\section{Results and Discussion}

The taxonomic features of the SIS fishes identified during the course of the study are presented with their occurrence and seasonal abundance in Table 2. A total number of 78 small indigenous species (SIS) of fish was identified belonging to 10 orders, 25 families, 04 sub-families and 55 genera. Among the SIS fishes obtained, the family Cyprinidae was the dominant group in regard to genera, species and specimens. The abundance of the species was found to be vary with seasons and locations. Variety of minnows (Darkina, Chela, Mola etc) and barbs was found to be abundant.

Punti (Puntius spp.), Tengra (Mystus spp.), Mola (Amblypharyngodon mola) and Guchi baim (Mastacembalus pancalus ) were maximum in number in terms of their quantity and seasonal abundance. Bacha (Eutropiichthys vacha), Elang (Rasbora elanga), Shilong (Silonia silondia) and Joya (Aspidoparia morar) were minimum in number. According to IUCN-Redbook (2000), Sar punti (Puntius sarana) was a critically endangered species in perspective of the whole country. But in the present study good quantity of Sar punti was found. Islam and Ahmed (2010) also reported Puntius sarana from Trishal, Mymenshingh.

The catch of SIS observed was the highest in August- September and was the lowest in March showing a seasonal variation. The abundance of SIS increased with rainy season when rivers, floodplain areas, beels, ponds, ditches are fulfiled with water. Availability of SIS started to decrease after post monsoon. In that period, SIS is easy to harvest. Thus, it was observed that, the catch of SIS increases in December. Karim (2003) observed that the abundance of fishes started to increase with rainy season and the pick harvesting season was in the late monsoon which also coincides with the present report.

It was observed that the abundance of SIS was found to be varied in number, size and type at different investigation sites. Some were plenty in one site, whereas some were rare or absent. The reason behind these variations depends on the basin topography, food availability and fishing intensity (Huda et al. 2009). In Mohanganj, the highest (62) species of SIS were found. A big haor (Dingaputa) is in confluent with the waterbodies of Mohanganj upazilla which is responsible for richness and diversity of SIS in this upazilla. Other upazillas viz. Khaliajuri, Purbodhola, Madan, Netrakona Sadar, Barhatta, Kalmakanda and Durgapur contained $61,61,55,55,54,51$ and 17 species as SIS respectively.

In this investigation, 78 SIS were found. Ali (1997) recorded 143 species of SIS from the waters of Bangladesh.The waterbody of Netrakona is little in comparison to the total aquatic area of Bangladesh. But, it can be said that the abundance of SIS would not be little in comparison to that of the whole country. 
Table 2. Taxonomy of SIS with their local names, occurrence in investigation sites and seasonal abundance of Netrakona district.

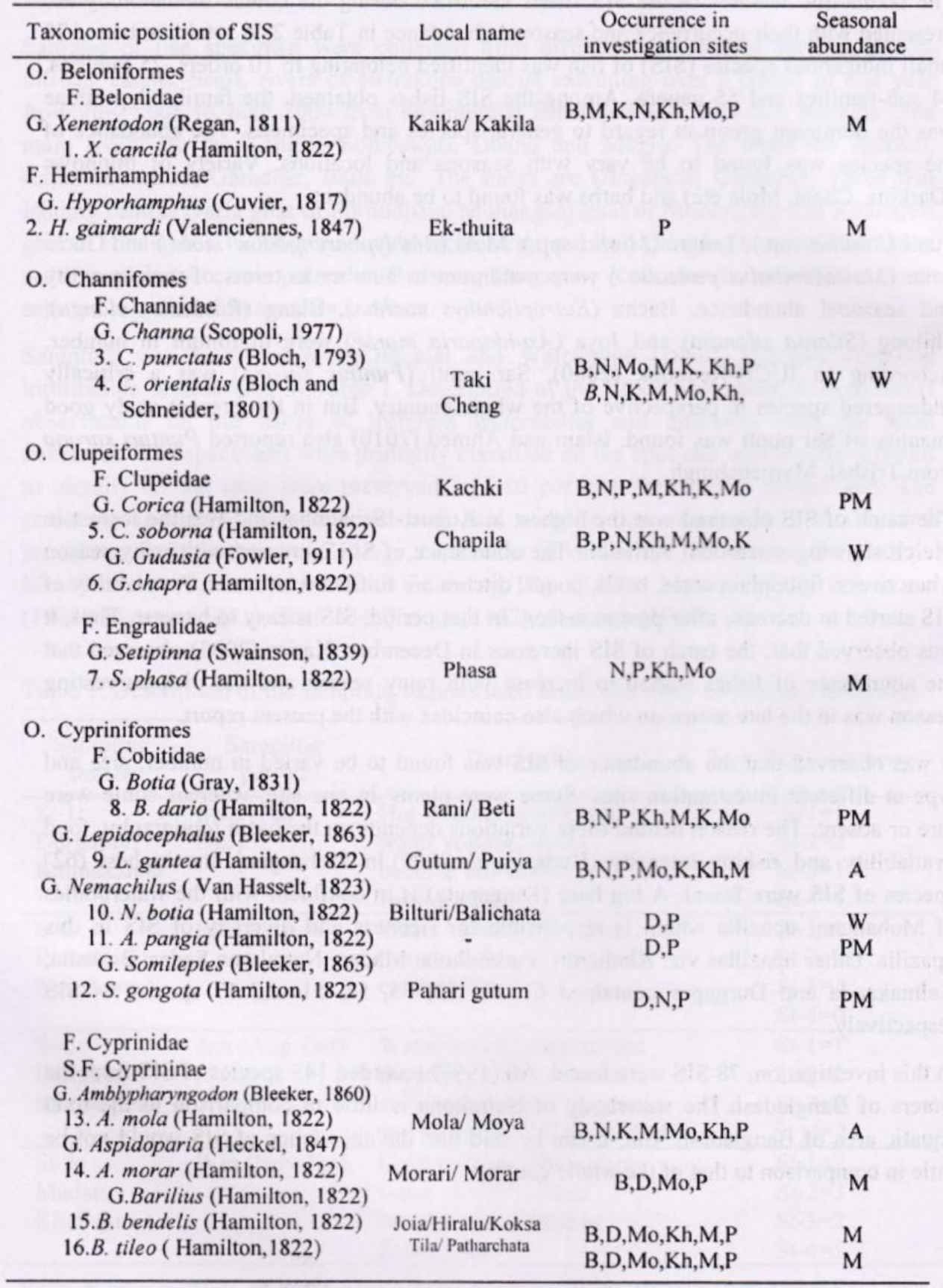


Contd.

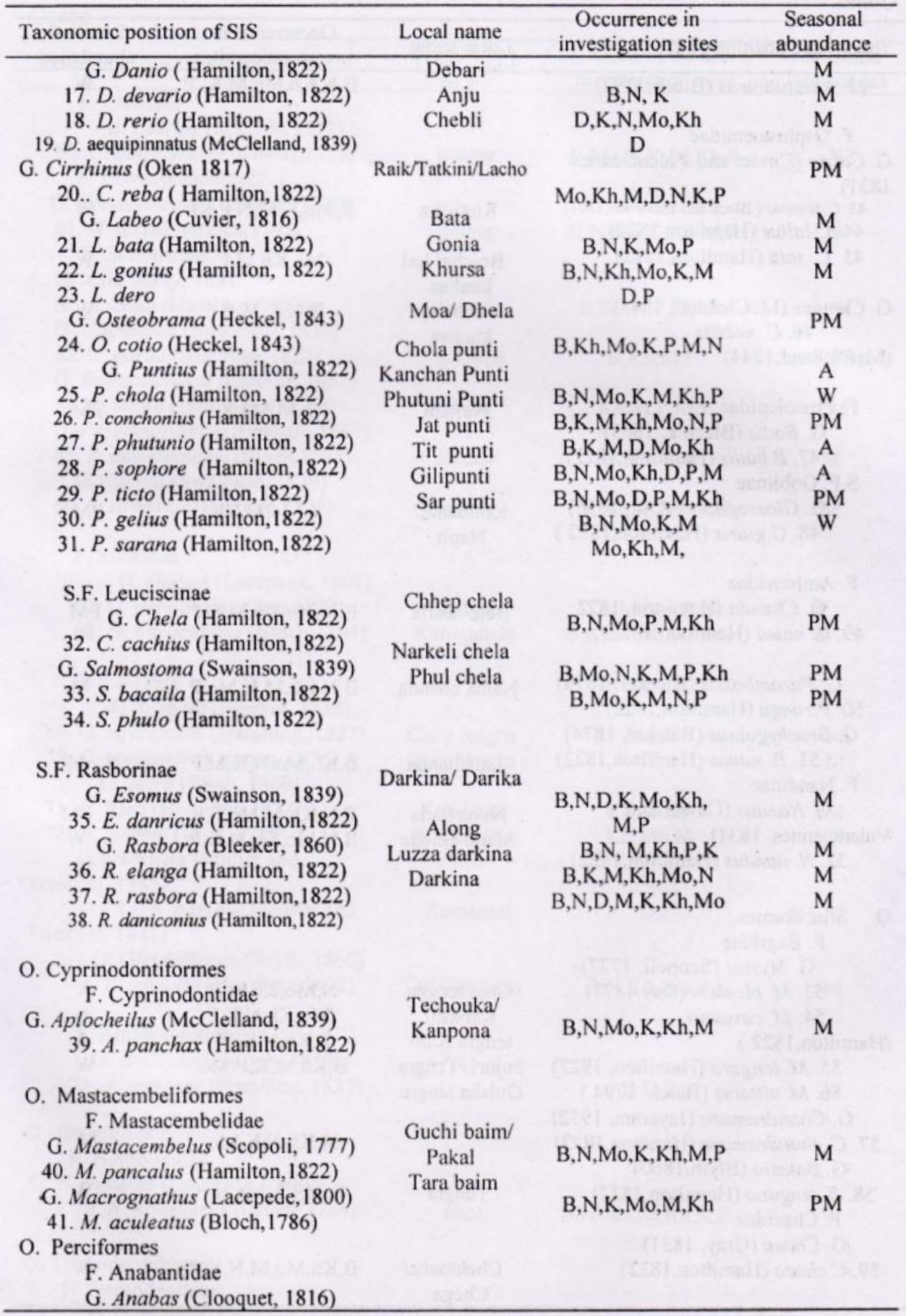


Contd.

\begin{tabular}{|c|c|c|c|}
\hline Taxonomic position of SIS & Local name & $\begin{array}{c}\text { Occurrence in } \\
\text { investigation sites }\end{array}$ & $\begin{array}{c}\text { Seasonal } \\
\text { abundance }\end{array}$ \\
\hline 42. A.testudineus (Bloch, 1792) & Koi & $\mathrm{B}, \mathrm{N}, \mathrm{Kh}, \mathrm{Mo}_{0}, \mathrm{M}, \mathrm{K}, \mathrm{P}$ & W \\
\hline \multicolumn{4}{|l|}{$\begin{array}{l}\text { F. Osphronemidae } \\
\text { G. Colisa (Cuvier and Valenciennes }\end{array}$} \\
\hline 1831) & & & \\
\hline $\begin{array}{l}\text { 43. C. fasciata (Bloch and Schneider, 1801) } \\
\text { 44. C lalius (Hamilton, 1822) }\end{array}$ & Khalisha & $\mathrm{B}, \mathrm{Mo}, \mathrm{K}, \mathrm{M}, \mathrm{N}, \mathrm{P}, \mathrm{Kh}$ & W \\
\hline 45. C. sota (Hamilton, 1822) & $\begin{array}{l}\text { Boicha/ Lal } \\
\text { khalisa }\end{array}$ & $\mathrm{Mo}, \mathrm{Kh}, \mathrm{M}, \mathrm{P}$ & W \\
\hline $\begin{array}{l}\text { G. Ctenops (McClelland, 1844) } \\
\text { 46. C. nobilis } \\
\text { (McClelland, 1844) }\end{array}$ & $\begin{array}{l}\text { Chuna } \\
\text { khalisa }\end{array}$ & $\mathrm{B}, \mathrm{N}, \mathrm{K}, \mathrm{M}, \mathrm{P}$ & w \\
\hline $\begin{array}{l}\text { F. Pristolepidae } \\
\text { G. Badis (Bleeker, 1863) } \\
\text { 47. B.badis (Hamilton,1822) }\end{array}$ & Neftani & $\mathrm{Kh}, \mathrm{M}, \mathrm{Mo}, \mathrm{K}$ & PM \\
\hline S.F. Gobiinae & & & \\
\hline $\begin{array}{l}\text { G. Glossogobius (Gill, 1856) } \\
\text { 48. G.giuris (Hamilton,1822) }\end{array}$ & $\begin{array}{l}\text { Koi bandi/ } \\
\text { Napit }\end{array}$ & $\mathrm{K}, \mathrm{Mo}, \mathrm{M}, \mathrm{Kh}$ & PM \\
\hline F. Ambassidae & & & \\
\hline $\begin{array}{l}\text { G. Chanda (Hamilton, } 1822 \\
\text { 49. C. nama (Hamilton, 1822) }\end{array}$ & Bele/ Baila & $\mathrm{B}, \mathrm{N}, \mathrm{Mo}, \mathrm{Kh}, \mathrm{M}, \mathrm{K}, \mathrm{P}$ & PM \\
\hline G. Parambassis (Bleeker, 1874) & Nama chanda & $\mathrm{B}, \mathrm{N}, \mathrm{Kh}, \mathrm{M}, \mathrm{K}, \mathrm{Mo}, \mathrm{P}$ & M \\
\hline $\begin{array}{l}\text { 50. P. ranga (Hamilton, } 1822) \\
\text { G. Brachygobius }(\text { Bleeker, 1874) }\end{array}$ & & & \\
\hline $\begin{array}{l}\text { 51. B. nunus (Hamilton, 1822) } \\
\text { F. Nandidae }\end{array}$ & Lal chanda & $\mathrm{B}, \mathrm{Kh}, \mathrm{Mo}, \mathrm{N}, \mathrm{K}, \mathrm{M}, \mathrm{P}$ & M \\
\hline $\begin{array}{l}\text { F. Nandidae } \\
\text { G. Nandus (Cuvier and }\end{array}$ & & BNKKMMoPK & \\
\hline $\begin{array}{l}\text { Valenciennes, 1831) } \\
\text { 52. N. nandus (Hamilton, 1822) }\end{array}$ & Meni/Bheda & $\begin{array}{l}\mathrm{B}, \mathrm{N}, \mathrm{Kh}, \mathrm{M}, \mathrm{Mo}, \mathrm{P}, \mathrm{K} \\
\mathrm{B}, \mathrm{N}, \mathrm{Mo}, \mathrm{Kh}, \mathrm{M}, \mathrm{K}, \mathrm{P}\end{array}$ & $\begin{array}{l}\text { PM } \\
\mathrm{W}\end{array}$ \\
\hline $\begin{array}{l}\text { O. Siluriformes } \\
\text { F. Bagridae }\end{array}$ & & & \\
\hline G. Mystus (Scopoli, 1777) & & & \\
\hline 53. M. bleekeri (Day, 1877) & Guja tengra & $\mathrm{N}, \mathrm{Mo}, \mathrm{Kh}, \mathrm{M}, \mathrm{P}$ & A \\
\hline 54. M. cavasius & Kabashi & $\mathrm{Mo}, \mathrm{Kh}, \mathrm{N}, \mathrm{K}, \mathrm{P}$ & A \\
\hline (Hamilton, 1822) & tengra Kalo & $\mathrm{B}, \mathrm{Kh}, \mathrm{N}, \mathrm{K}, \mathrm{M}$ & A \\
\hline 55. M. tengara (Hamilton, 1922) & bujuri /Tengra & $\mathrm{B}, \mathrm{Kh}, \mathrm{M}, \mathrm{K}, \mathrm{P}, \mathrm{Mo}$ & w \\
\hline 56. M. vittatus (Bloch, 1794 ) & Gulsha tengra & & \\
\hline G. Chandramara (Jayaram, 1972) & & & \\
\hline $\begin{array}{l}\text { 57. C. chandramara (Hamiton, 1822) } \\
\text { G. Batasio (Blvth, 1860) }\end{array}$ & - & $\mathrm{M}, \mathrm{Kh}, \mathrm{N}, \mathrm{K}, \mathrm{Mo}$ & M \\
\hline $\begin{array}{l}\text { G. Batasio (Blyth, 1860) } \\
\text { 58. B. tengana (Hamilton 1822) }\end{array}$ & Tengra & $\mathrm{B}, \mathrm{M}, \mathrm{Kh}, \mathrm{Mo}, \mathrm{N}, \mathrm{P}$ & w \\
\hline F. Chacidae & & & \\
\hline $\begin{array}{l}\text { G. Chaca (Gray, 1831) } \\
59 \text { C. chaca (Hamilton.1822) }\end{array}$ & & & \\
\hline 59. C.chaca (Hamilton, 1822) & $\begin{array}{l}\text { Chekmaka/ } \\
\text { Chega }\end{array}$ & $\mathrm{B}, \mathrm{Kh}, \mathrm{Mo}, \mathrm{M}, \mathrm{N}, \mathrm{K}, \mathrm{P}$ & W \\
\hline
\end{tabular}


Contd.

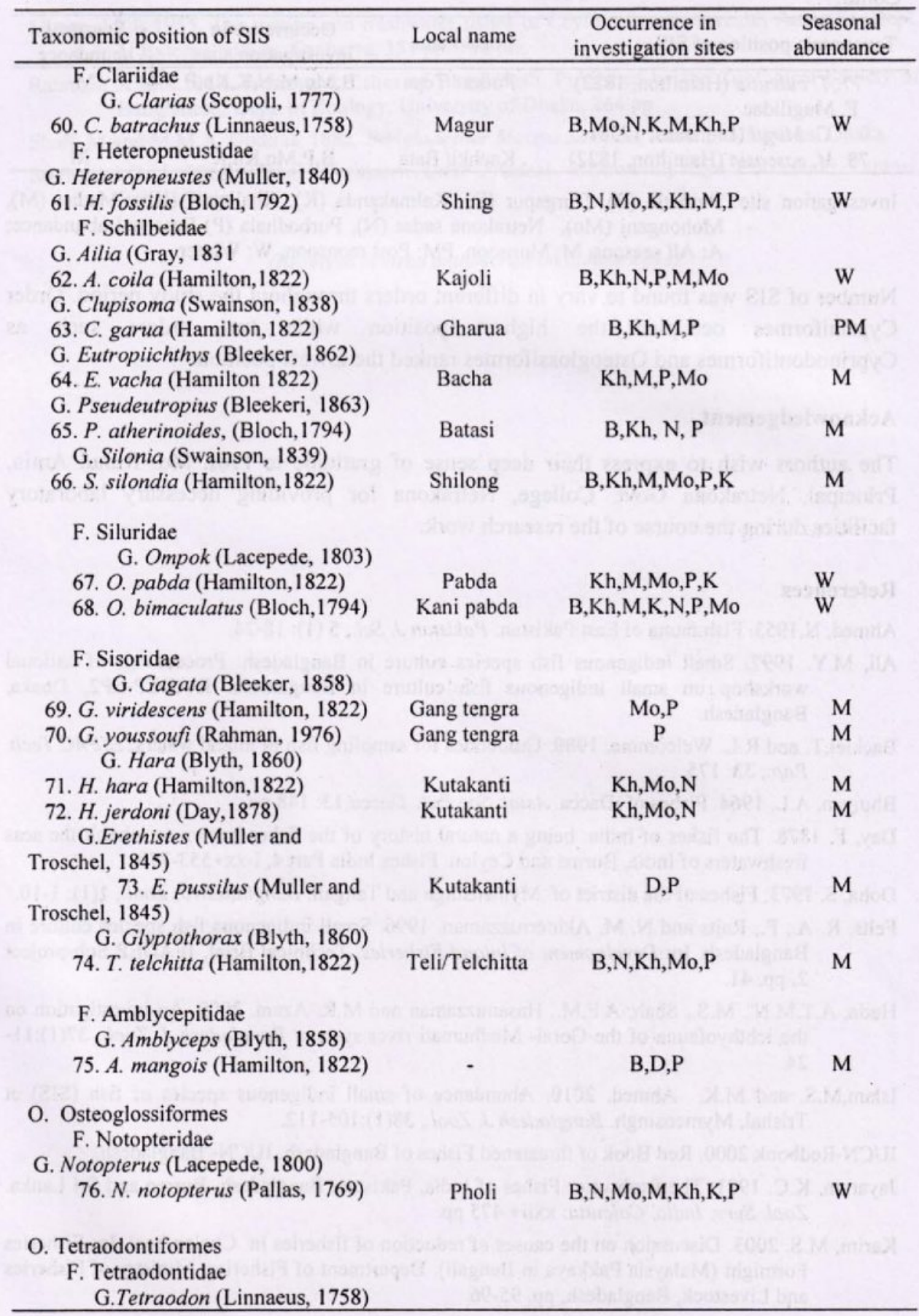


Contd.

\begin{tabular}{cllc}
\hline Taxonomic position of SIS & Local name & $\begin{array}{c}\text { Occurrence in } \\
\text { investigation sites }\end{array}$ & $\begin{array}{c}\text { Seasonal } \\
\text { abundance }\end{array}$ \\
\hline $\begin{array}{l}\text { 77. T. cutcutia (Hamilton, 1822) } \\
\text { F. Mugilidae }\end{array}$ & Potka/ Tepa & B,Mo,M,N,K,Kh,P & $\mathrm{M}$ \\
$\begin{array}{c}\text { G. Mugil (Linnaeus, 1758) } \\
\text { 78. cascasia (Hamilton, 1822) }\end{array}$ & Kachki/ Bata & B,P,Mo,Kh,K & $\mathrm{M}$ \\
\hline
\end{tabular}

Investigation site: Barhatta (B), Durgapur (D), Kalmakanda (K), Khaliajuri (Kh), Madan (M), Mohonganj (Mo), Netrakona sadar (N), Purbodhala (P) Seasonal abundance: A: All seasons, M: Monsoon, PM: Post monsoon, W: Winter

Number of SIS was found to vary in different orders throughout the study period. Order Cypriniformes occupied the highest position while two orders such as Cyprinodontiformes and Osteoglossiformes ranked the lowest position.

\section{Acknowledgement}

The authors wish to express their deep sense of gratitude to Prof. Md. Ruhul Amin, Principal, Netrakona Govt. College, Netrakona for providing necessary laboratory facilities during the course of the research work.

\section{References}

Ahmed, N.1953. Fish fauna of East Pakistan. Pakistan J. Sci., 5 (1): 18-24.

Ali, M.Y. 1997. Small indigenous fish species culture in Bangladesh. Proceedings of national workshop on small indigenous fish culture in Bangladesh. IFADEP-SP2, Dhaka, Bangladesh.

Backiel,T. and R.L. Welcomme. 1980: Guidelines for sampling fish in inland waters. EIFAC Tech. Pap., 33: 175.

Bhuiyan, A.L. 1964. Fishes of Dacca. Asiat. Soc.Pak. Dacca,13: 148 pp.

Day, F. 1878. The fishes of India: being a natural history of the fishes known to inhabit the seas freshwaters of India, Burma and Ceylon. Fishes India Part 4, i-xx+553-779.

Doha, S. 1973. Fishes of the district of Mymensingh and Tangail. Bangladesh J. Zool., 1(1): 1-10.

Felts, R. A., F., Rajts and N. M. Akhterruzzaman. 1996. Small indigenous fish species culture in Bangladesh. In: Development of Inland Fisheries. Technical Brief, IFADEP Sub-project 2, pp. 41 .

Huda, A.T.M.N., M.S., Shah, A.F.M., Hasanuzzaman and M.R. Azam. 2009. An investigation on the ichthyofauna of the Gorai- Madhumati river system. Bangladesh J. Zool., 37(1):1124.

Islam,M.S. and M.K. Ahmed. 2010. Abundance of small indigenous species of fish (SIS) at Trishal, Mymensingh. Bangladesh J. Zool., 38(1):105-112.

IUCN-Redbook 2000. Red Book of threatened Fishes of Bangladesh. IUCN-Bangladesh.

Jayaram, K.C. 1981. The freshwater Fishes of India, Pakistan, Bangladesh, Burma and Sri Lanka. Zool. Surv. India, Calcutta: xxii $475 \mathrm{pp}$.

Karim, M.S. 2003. Discusșion on the causes of reduction of fisheries in Chalan beel. In: Fisheries Fortnight (Malaysia Pakkaya in Bengali). Department of Fisheries, Ministry of Fisheries and Livestock, Bangladesh, pp. 95-96. 
Munro, I.S.R.1955. The marine and freshwater fishes of Ceylon. Commonwealth Australia, Dept. of External affairs, Canberra. $351 \mathrm{pp} .+56 \mathrm{pls}$.

Rahman, A.K.A.1989. Freshwater fishes of Bangladesh. Published by the Zoological Society of Bangladesh, Dept. of Zoology, University of Dhaka, 264 pp.

Shafi, M.and M.M.A. Quddus, 1882. Bangladesher Matsya Sampad, Kabir publications, Dhaka.

Srivastava,G. J. 1968. Fishes of eastern Uttar Pradesh. Vishwavidyalaya Prakashan, Varansi, India, $163 \mathrm{pp}$.

(Received revised manuscript on 6 June 2014) 